\title{
Spatial and temporal variations in surface velocity and basal drag across the tongue of the polythermal glacier midre Lovénbreen, Svalbard
}

\author{
D.M. RIPPIN, ${ }^{1 *}$ I.C. WILLIS, ${ }^{1}$ N.S. ARNOLD, ${ }^{1}$ A.J. $\mathrm{HODSON}^{2}$ M. BRINKHAUS $^{2}$ \\ ${ }^{1}$ Scott Polar Research Institute and Department of Geography, University of Cambridge, Lensfield Road, \\ Cambridge CB2 1ER, UK \\ E-mail: d.rippin@hull.ac.uk \\ ${ }^{2}$ Department of Geography, University of Sheffield, Winter Street, Sheffield S10 2TN, UK
}

\begin{abstract}
We present results of a detailed investigation of surface motion across the tongue of a polythermal glacier, midre Lovénbreen, Svalbard, during the 1999 summer. Surface velocities in the warm-based upper tongue increased during periods of enhanced surface melting and rainfall events, and force-balance analysis indicates that these velocity variations were locally forced, probably by fluctuations in subglacial water pressure. Surface speed-ups were also observed on the cold-based lower tongue (which acted as a sticky spot, through which there was minimal subglacial drainage for most of the summer), but these were largely non-locally forced by longitudinal coupling to the faster-moving ice up-glacier. On one occasion, however, a large, rapid input of surface water to the glacier reduced the basal drag beneath the cold-based lower tongue, presumably due to hydraulic jacking. This resulted in locally forced enhanced surface velocities across the entire tongue, accompanied by a breaching of the lower tongue and an outburst of subglacially stored water.
\end{abstract}

\section{INTRODUCTION}

It is now widely recognized that water is a fundamental control on glacier dynamics (Willis, 1995; Fischer and Clarke, 2001) and that significant basal motion occurs only where basal ice is at the pressure-melting point and water exists at the bed (Echelmeyer and Wang, 1987; Rabus and Echelmeyer, 1997; Waller, 2001). This is because: (i) the mechanisms of regelation and enhanced ice deformation are most effective at or near the pressure-melting point; (ii) basal water reduces the basal traction (drag) between the ice and parts of the bed; (iii) pressurized water can exert a downglacier force on up-glacier facing ice surfaces in cavities in the lee of bedrock bumps (known as 'hydraulic jacking'; Röthlisberger and Iken, 1981); and (iv) pressurized water can reduce the strength or viscosity of subglacial sediments, promoting their deformation.

Studies of temperate glaciers have shown that surface velocity variations on a variety of time-scales may be ascribed to changes in basal motion, due to locally forced changes in basal drag, associated with variations in subglacial water pressure (Iken and Bindschadler, 1986; Kamb and Engelhardt, 1987; Lliboutry, 1987; Mair and others, 2001). Measurements at the base of boreholes suggest that, at least over short time periods of hours to days, variations in surface motion are primarily due to ice/ bed decoupling and sliding rather than enhanced sediment deformation (Blake and others, 1994; Iverson and others, 1995; Fischer and Clarke, 1997). Short periods of rapid sliding occur early in the melt season when large amounts of surface-derived water reach the bed, but the subglacial drainage network is distributed and hydraulically inefficient. This leads to high steady-state water pressures and even

*Present address: Department of Geography, University of Hull, Cottingham Road, Hull HU6 7RX, UK. higher transient pressures across large areas of the bed (Iken and others, 1983; Mair and others, 2001). By contrast, later in the melt season, subglacial discharges are typically higher, and hydraulically efficient channelized drainage dominates. This results in lower steady-state and transient water pressures, and high-velocity events are less common.

Force-balance analysis on a few temperate glaciers has shown that although variations in surface velocities are primarily locally forced by local changes in basal drag, velocity variations over some parts of glaciers may be nonlocally forced by changes in longitudinal and/or lateral resistance (e.g. Iken and Truffer, 1997; Mair and others, 2001). Identifying the circumstances giving rise to local vs non-local forcing of ice masses remains an important goal in glaciology.

Compared with temperate glaciers, there have been few studies of the dynamics of polythermal glaciers. The few studies that have been undertaken suggest that seasonal and intra-seasonal surface velocity variations occur, although the precise mechanisms responsible are not known (e.g. Iken, 1974; Andreasen, 1985; Rabus and Echelmeyer, 1997; Copland and others, 2003). At John Evans Glacier, Ellesmere Island, Canada, seasonal surface velocity variations are due to surface water reaching the glacier bed in summer, and intra-seasonal variations reflect short-term variations in surface water inputs to the subglacial drainage system (Copland and others, 2003).

It is important to understand the dynamics of polythermal glaciers, because large parts of contemporary (and Pleistocene) ice sheets are (were) polythermal, and thus polythermal glaciers are better analogues for these ice sheets than temperate glaciers (Arnold and Sharp, 1992; Heine and McTigue, 1996; Payne and others, 2000). Furthermore, global warming may be particularly marked in the Arctic (Fleming and others, 1997; McCarthy and others, 2001; $\mathrm{ACIA}, 2004)$ and have a significant impact on the thermal 


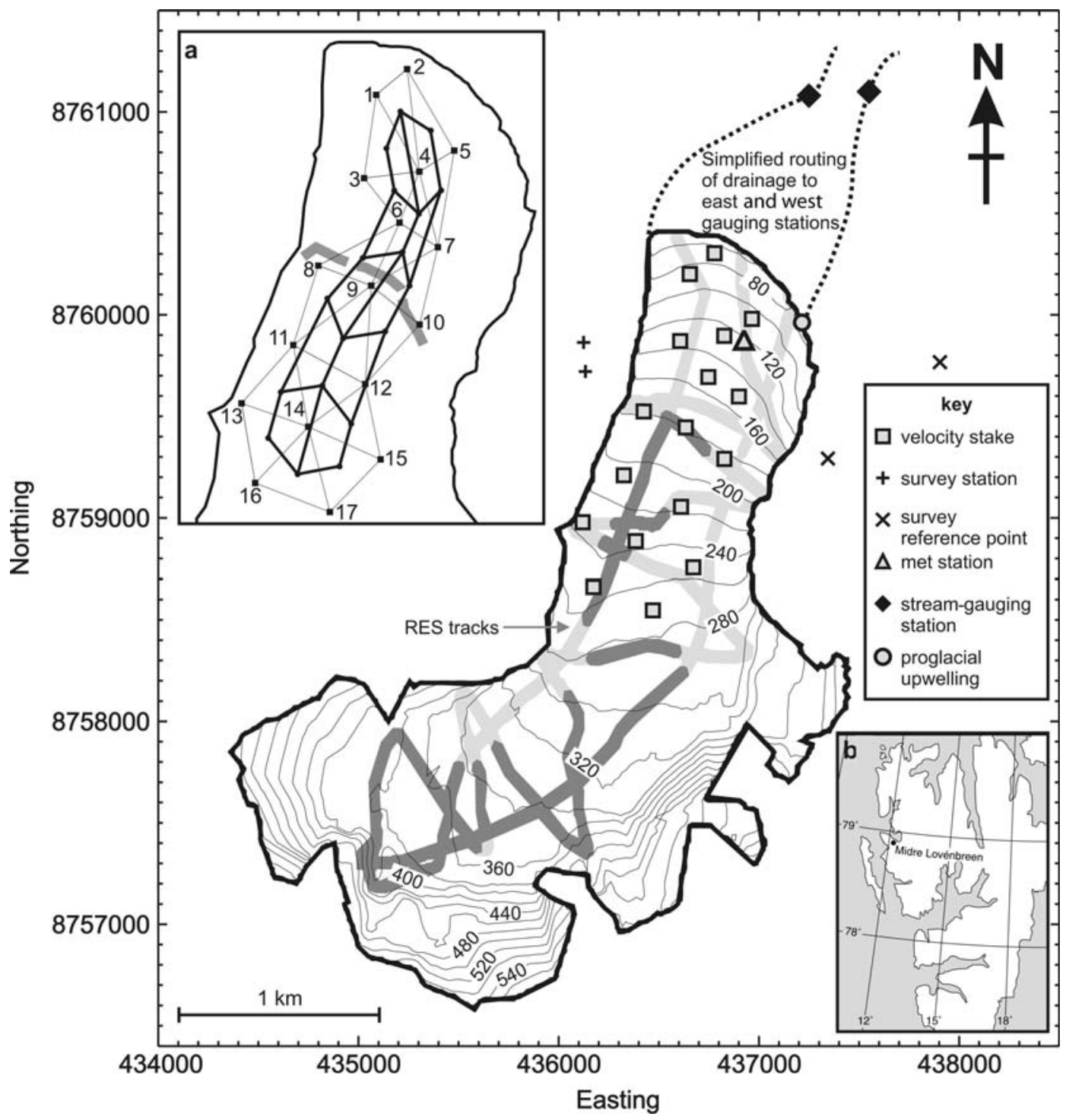

Fig. 1. Surface contours ( $\mathrm{m}$ ) on midre Lovénbreen (after Rippin and others, 2003). Survey stations, reference points and velocity stakes are shown, as are the locations of the meteorological station, stream-gauging stations and the proglacial upwelling. Radio-echo sounding (RES) tracks (J. Moore, unpublished data; cf. Rippin and others, 2003) are shown, indicating where cold (light grey) and warm (dark grey) basal ice exists. Inset ' $a$ ' shows how the 17 velocity stakes are laid out to form 18 strain triangles (fine lines), which make up three interlinked hexagons (stake numbers are also marked). This structure also enables ten force-balance blocks to be constructed (thicker lines). The approximate boundary between warm and cold ice is also shown here as a thick grey line. Inset ' $b$ ' shows the location of midre Lovénbreen in Svalbard.

regime, hydrology, dynamics and thus mass balance of polythermal glaciers.

This paper has three main aims. The first is to monitor the surface motion across the tongue of a polythermal glacier at a high spatial and temporal resolution, to identify whether it experiences short-term velocity variations. The second is to use the surface motion measurements to calculate spatial and temporal variations in longitudinal, lateral and basal resistance using a force-balance approach. The third aim is to explain the variations in velocity and force-balance components with reference to changes in subglacial hydrology as inferred from meteorological and hydrological data.

\section{FIELD SITE}

Midre Lovénbreen $\left(78.53^{\circ} \mathrm{N}, 12.04^{\circ} \mathrm{E}\right)$ is an alpine-type valley glacier in northwest Spitsbergen, Svalbard (Fig. 1). The glacier is $\sim 6 \mathrm{~km}$ long, with an area of $\sim 5.5 \mathrm{~km}^{2}$, an elevation range of $\sim 50-600 \mathrm{~m}$ a.s.l. and a maximum thickness of $\sim 180 \mathrm{~m}$ (Rippin and others, 2003). The glacier is polythermal with a warm-based core, cold based ice around its snout and margins, and cold ice at its surface, although the winter cold wave is eliminated during the summer in the accumulation basins (Fig. 1) (Björnsson and others, 1996; Rippin and others, 2003). Surface water enters the glacier via a few crevasses and also via a large incised supraglacial stream which appears to enter the glacier $\sim 1000 \mathrm{~m}$ from the terminus. At the down-glacier boundary between warm and cold ice is a 'thermomechanical dam' where surface-derived subglacial water that has flowed through the permeable temperate ice meets the largely impermeable cold snout where subglacial drainage is more restricted (Rippin and others, 2003). Water above the dam does penetrate the cold snout and emerges proglacially as a pressurized upwelling from mid-summer onwards each year (Hodson and Ferguson, 1999). 
At the centre line, the glacier moves at velocities of 4.4-7.3 $\mathrm{m} \mathrm{a}^{-1}$ (Liestøl, 1988; Björnsson and others, 1996). Some research suggests that midre Lovénbreen is a surgetype glacier (e.g. Liestøl, 1988; Lefauconnier and others, 1999; Hansen, 2003), while other work has argued against this (Hambrey and others, 1999; Jiskoot and others, 2000). There is, as yet, no consensus, although it seems most likely that this is a non-surge-type glacier.

\section{METHODS}

\section{Surface velocities, strain rates and force balance}

Glacier surface motion was monitored from repeated surveys of a network of 17 stakes, drilled into the glacier surface, using a Geodimeter 410 Total Station. The stake network was set out on the glacier tongue, and positioned to cover longitudinal variations in basal thermal regime, and lateral variations in the likely structure of any subglacial drainage system (Rippin and others, 2003). The resultant network was centred slightly west of the centre line (Fig. 1). Surveying took place from two fixed sites on the western valley side, with reference to two fixed points on the eastern side (Fig. 1). To investigate the components of the force balance, the stake network was devised to form 18 strain triangles, arranged to produce three interlinked hexagons (Fig. 1). This layout enabled ten theoretical ice blocks to be delineated on which the balance of forces could be determined (Fig. 1a).

Surveys were conducted between 5 July and 9 August 1999 on each day that weather conditions were favourable, typically every 2-3 days. A full survey consisted of two sightings to each glacier stake from each survey station, and three surveys to each of the fixed reference points from each survey station. For each survey, there were thus a total of four measurements to each glacier stake. Stake coordinates and positional errors were then determined using a leastsquared estimation program (General Adjustment Program (GAP) version 6.11, developed in 1992 by J. Chandler and J.S. Clark of City University, London). Velocities in the alongflow direction and associated errors were then calculated (Mair and others, 2001; Rippin, 2002).

Surface strain rates were calculated from the deformation of the 18 strain triangles, following the method of Mair (1997), who adapted the technique of Ramsay (1967). The technique involves determining the centre of each strain triangle as well as the two perpendicular principal strains and their angles of orientation for each period between two consecutive surveys (Mair and others, 2001). These strain rates were then used to calculate the components of the force balance operating on the ten theoretical ice blocks (Van der Veen and Whillans, 1989a; Mair, 1997; Mair and others, 2001).

Van der Veen and Whillans (1989b) first discovered the presence of isolated sites of high basal drag ('sticky spots'), unrelated to topographic highs, along the Byrd Station strain network, Antarctica, and suggested that basal drainage was important in controlling overall bed friction. Here, we employ their relatively simple plug-flow method, which avoids the numerical instabilities often encountered in more complex inverse methods (Blatter, 1995; Mair and others, 2001). The measured surface strain rates and the area of the sides of each block are used to calculate longitudinal and shear forces. Basal drag is finally calculated by subtracting the driving stress. Force-balance analysis was carried out to identify the dominant controls on the resistance to flow. Driving stress is the dominant factor promoting glacier motion, while basal drag, longitudinal forces and lateral shear forces generally act to resist it. The ratio of basal drag $\left(\tau_{\mathrm{b}}\right)$ to the driving force $\left(\tau_{\mathrm{d}}\right)$ was used to identify the proportion of the driving stress resisted by basal drag. $\tau_{\mathrm{b}} / \tau_{\mathrm{d}}<1$ if some resistance to flow comes from non-local sources, and $\tau_{\mathrm{b}} / \tau_{\mathrm{d}}>1$ if flow is driven by forces in addition to the driving force.

One of the main potential weaknesses of this method is the way in which the flow-law parameter $A$ is dealt with. On temperate glaciers, where the ice temperature is close to $0^{\circ} \mathrm{C}$ throughout, $A$ is usually assumed to be constant, and strain rates are usually assumed to be constant with depth (Hooke and others, 1989; Iken and Truffer, 1997; Mair, 1997). However, on the polythermal midre Lovénbreen these assumptions are less valid, though there is a great degree of uncertainty surrounding the value of $A$ due to factors such as melting, grain-size variations, impurities, ice density and ice fabric, many of which are affected by temperature (Hooke, 1981; Van der Veen, 1999).

We carried out a series of experiments to investigate the sensitivity of the force-balance components to changing values of the parameter $A$. Although a uniform change in ice stiffness affects the magnitudes of the resistive force-balance components, it does not change the direction in which they act, or significantly change the relative role of the forces in controlling the ice-block dynamics. The situation is, however, more complicated where cold and warm ice exists within the same ice block, as is thought to be the case on midre Lovénbreen in the middle and upper tongue (where cold ice overlies temperate ice towards the bed). Consequently, ideally, the stiffness parameter should perhaps be allowed to vary with depth. However, the sensitivity analysis presented above suggests that only the magnitude of forces is affected by the flow parameter. Due to the general uncertainties and limitations inherent in the forcebalance technique (Mair, 1997), the uncertainty in the value of $A$ for a given ice temperature and the fact that there are no field data to support the idea of depth-dependent strain rates on midre Lovénbreen, we use a fixed value of $A$ of $3.96 \times 10^{-24} \mathrm{~s}^{-1} \mathrm{~Pa}^{-3}$, which equates to an ice temperature of between $-1{ }^{\circ} \mathrm{C}$ and $-2{ }^{\circ} \mathrm{C}$. This provides for slightly stiffer ice than would perhaps be employed for temperate ice, and is thus considered to be a suitable compromise for the polythermal state dominant over much of the glacier tongue. The potential error resulting from applying a spatially homogeneous flow parameter is considered to be as unknown as the uncertainties surrounding the flow-law formula itself, and, given other uncertainties here, a depthindependent flow parameter is considered acceptable (Mair, 1997; cf. Rippin, 2002).

Our sensitivity tests indicate that it is the magnitudes of the resistive force-balance components that are changed as $A$ varies, but that it does not change the direction or role of each force significantly. It is therefore patterns, and not magnitudes, of force-balance components that will be discussed, and no significance will be attached to the actual force-balance values. A more detailed overview of the procedures for calculating surface strain rates and forcebalance components can be found in Mair and others (2001), and full details of its application here are given in Rippin (2002). 
Errors in stake location and surface velocities were determined from four measurements to each stake on each day (two from each survey station). Strain-rate errors were calculated by deriving three sets of possible coordinates for each stake on each day: the measured stake coordinates; the measured stake coordinates plus the maximum possible locational errors; and the measured stake coordinates minus the maximum possible errors. By calculating strain rates using all possible combinations of stake coordinates, nine possible calculations of strain rates for each stake in each time period were made. The mean strain rate and standard deviations were then determined from these nine measurements for each stake. The force-balance errors were determined using the same procedure. In this way we were able to propagate the calculated errors in velocity measurements through to strain rates and force-balance measurements.

\section{Meteorological and hydrological data}

Hourly air-temperature data were recorded at an automatic weather station located on the glacier at $\sim 110 \mathrm{ma.s.I.}$, $\sim 350 \mathrm{~m}$ from the terminus (Fig. 1). Precipitation data were collected by the Norske Meteorlogiske Institutt, in the nearby settlement of Ny-Ålesund, $\sim 4 \mathrm{~km}$ northwest of the glacier terminus, at 0700 and $1900 \mathrm{~h}$ each day.

Proglacial stream discharge and turbidity data were recorded every hour at two temporary gauging sites, on streams draining the western and eastern parts of the glacier. The temporary gauging stations were located at stable stream cross-sections as close to the glacier snout as possible $(\sim 700$ and $1000 \mathrm{~m}$ from the front respectively) (Fig. 1). For each station, water stage and turbidity were measured every hour using, respectively, a Druck pressure transducer and a Partech IR-15C infrared turbidity sensor wired to a Campbell Scientific data logger. Stage data were converted to discharge using a stage-discharge curve derived from daily measurements of discharge made using the standard velocity-area method. Discharge errors were typically $<10 \%$ under typical flows but rose to $\sim 15 \%$ during maximum flows (Hodson and Ferguson, 1999; Hodson and others, 2000).

Additionally, the discharge of the subglacially routed water that emerged proglacially as a pressurized upwelling, and entered the eastern stream upstream of the gauging station, was calculated using a chemically based mixing model:

$$
Q_{\text {gauge }} C_{\text {gauge }}=Q_{\text {sub }} C_{\text {sub }}+Q_{\text {lat }} C_{\text {lat }}
$$

where $Q$ and $C$ represent discharge $\left(\mathrm{m}^{3} \mathrm{~s}^{-1}\right)$ and $\mathrm{Si}$ concentrations $\left(\mathrm{mg} \mathrm{L}^{-1}\right)$ respectively, and subscripts gauge, sub and lat denote total (at the gauging station), subglacial and lateral components respectively (i.e. total runoff in the eastern river and the two drainage components that supply it). Assuming conservation of mass, Equation (1) can be rearranged to calculate the discharge of the proglacial upwelling. This approach was adopted because the channel immediately downstream of the upwelling was unstable, and made use of dissolved $\mathrm{Si}$ determined from filtered samples collected at the various sites. It was assumed that mixing of the turbid, chemically concentrated subglacial water with the dilute lateral stream water was conservative with respect to $\mathrm{Si}$ in transit through the proglacial region to the gauging station downstream. The use of chemically based mixing models can be problematic in glacier basins when used to split bulk meltwaters into subglacial and englacial components (Sharp and others, 1995). In our study,

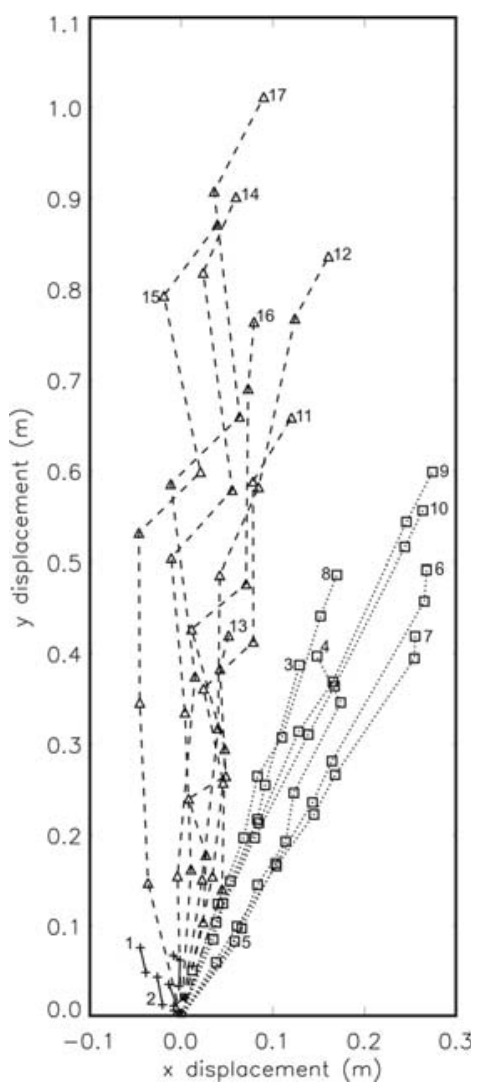

Fig. 2. Displacement of velocity stakes throughout the summer 1999 season for all stakes (numbered). Crosses and solid lines indicate northwest-trending stakes in the lower tongue (1 and 2); squares and dotted lines indicate northeast-trending stakes in the middle tongue (3-10); triangles and dashed lines indicate northerlytrending stakes in the upper tongue (11-17).

however, Si has been shown to be conservative throughout the proglacial plain due largely to the limited residence time of waters in transit through it (Mumford, 2002). Furthermore, we were able to allow the Si content of the subglacial and lateral stream waters to vary in our mixing model, as both sites were readily accessible and sampled on a daily basis for their dissolved Si content (Mumford, 2002).

\section{RESULTS AND ANALYSIS}

\section{Survey data and errors}

Fourteen full surveys were undertaken during summer 1999. The mean error in the positions of all glacier stakes was $0.011 \mathrm{~m}$ in $x$, and $0.013 \mathrm{~m}$ in $y$. Preliminary calculations of $x y$ coordinate positions showed that for surveys conducted only 1 or 2 days apart, displacements could not be resolved above the position errors. Combining adjacent periods where displacement patterns were similar resulted in a significant reduction in the errors. Therefore six periods were defined as follows: (1) 5-9 July, (2) 9-15 July, (3) 15-20 July, (4) 20-23 July, (5) 23 July-6 August and (6) 6-9 August, covering a total of 35 days.

The total displacement of the 17 stakes showed they could be separated into three groups, each displaying similar characteristics, representing the lower tongue (stakes 1 and 2), the middle tongue (stakes 3-10) and the upper tongue (stakes 11-17) (Fig. 2; cf. Fig. 1). The two lowest stakes moved only $\sim 0.08 \mathrm{~m}$ in a northwest direction over the 

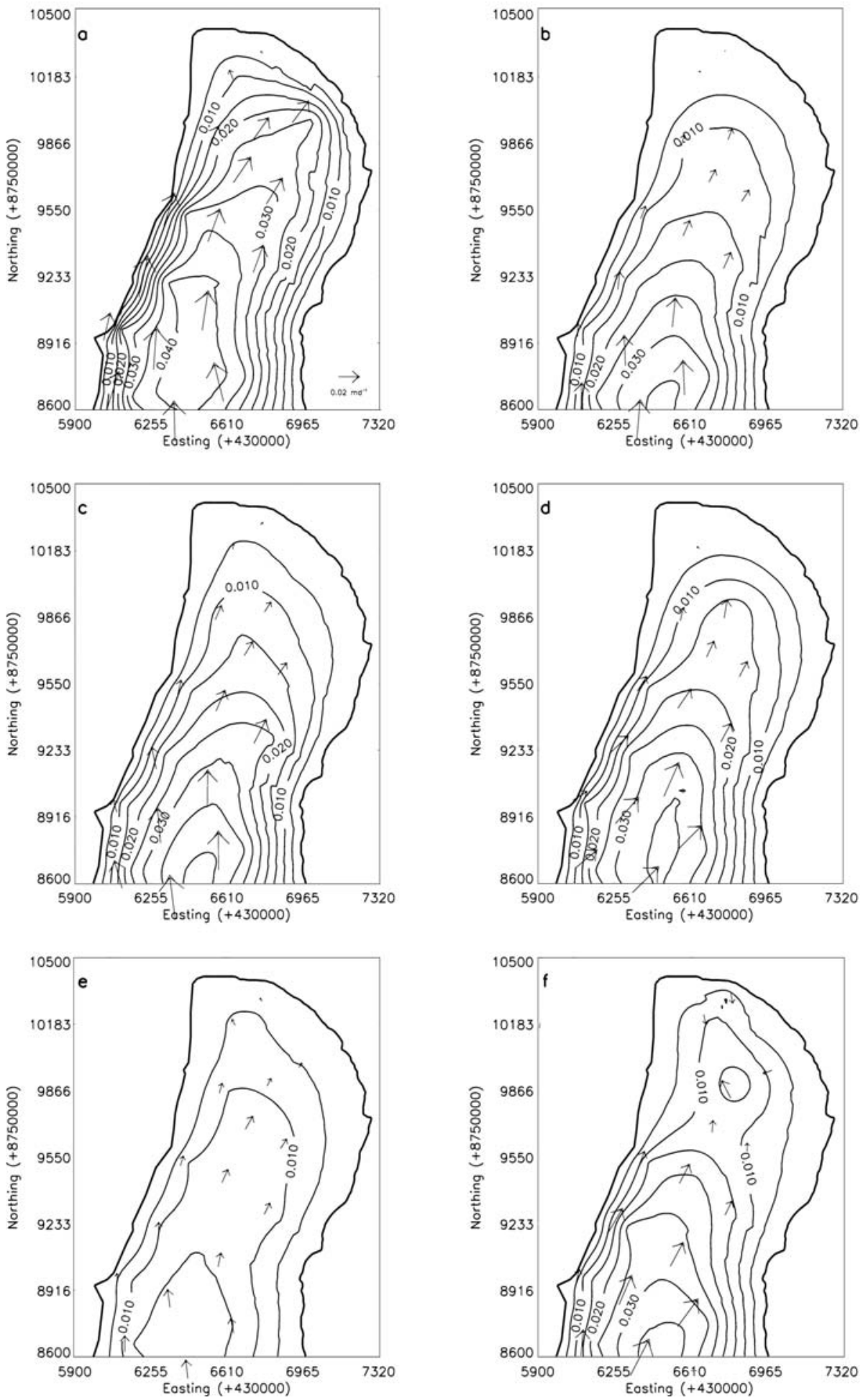

Fig. 3. Horizontal $x y$ surface velocities $\left(\mathrm{m} \mathrm{d}^{-1}\right)$ in the tongue. Arrows indicate $x y$ velocity azimuth, and their size is proportional to the measured $x y$ velocity magnitude (size guide shown in (a)). A linear kriging interpolation scheme was used to derive velocity contours. Contours are marked every $0.005 \mathrm{~m} \mathrm{~d}^{-1}$ and labelled every $0.01 \mathrm{~m} \mathrm{~d}^{-1}$. At the ice margin, $x y$ velocities are set to zero. (a) Period 1 (5-9 July); (b) period 2 (9-15 July); (c) period 3 (15-20 July); (d) period 4 (20-23 July); (e) period 5 (23 July-6 August); and (f) period 6 (6-9 August).

35 days; stakes $3-10$ moved $\sim 0.5 \mathrm{~m}$ in a northeast direction; and stakes 11-17 moved on average $\sim 0.8 \mathrm{~m}$ in a northerly direction, although stake 13 (close to the glacier's western margin) was an exception and moved only $\sim 0.45 \mathrm{~m}$.

\section{Surface velocities}

Mean velocity errors in the middle and upper tongue were small compared with $x y$ velocities in all six periods, averaging $\sim 28 \%$ of measured velocities. However, in periods 1-4, errors were larger than velocities in the lowest two stakes constituting the lower tongue ( $\sim 192 \%$ of measured velocities), due to very small rates of movement here. Where errors are large, we discuss only broad trends affecting large regions of the tongue.

Patterns of surface velocity for the six periods are shown in Figure 3. Velocities were generally higher during period 1 
than in any subsequent period (Fig. 3a). The whole tongue slowed down in period 2, although velocities remained relatively high in the upper tongue (Fig. $3 \mathrm{~b}$ ). In period 3 , velocities generally increased across the tongue (Fig. 3c). A slight slow-down in the upper tongue, and a speed-up in the lower tongue resulted in more similar velocities across the whole tongue in period 4 (Fig. 3d). Period 5 saw a substantial velocity drop (Fig. 3e), before a significant increase over most of the tongue, particularly the upper part, in period 6 (Fig. 3f). Thus, periods 1, 3, 4 and 6 were times of relatively high velocities, while periods 2 and particularly 5 were times of glacier slow-down.

\section{Surface longitudinal strain rates}

Errors in longitudinal strain rate were, on average, $35.11 \%$ of calculated strain rates. However, by excluding stake 13 , where errors were particularly high, errors are reduced to $21.94 \%$. In order to avoid over-interpretation where errors are significant, we do not attach any significance to individual measurements, and adopting the approach of Mair and others (2001), discuss only the broad patterns of surface strain rates influencing large areas of the tongue.

Patterns of surface longitudinal strain rates for the six periods are shown in Figure 4. The high velocities in periods 1, 4 and 6 were associated with longitudinal compression over most of the tongue, with possible longitudinal extension in the upper tongue (Fig. $4 \mathrm{a}, \mathrm{d}$ and $\mathrm{f}$ ). Compression increased towards the lower tongue in periods 1, 4 and 6 . Conversely, the high velocities in period 3 and the low velocities during periods 2 and 5 were all associated with smaller rates of longitudinal compression (Fig. 4b, c and e).

\section{Force balance}

The errors associated with $\tau_{\mathrm{b}}$ and $\tau_{\mathrm{b}} / \tau_{\mathrm{d}}$ are small in all cases (averaging $\sim 2.08 \%$ of calculated $\tau_{\mathrm{b}} / \tau_{\mathrm{d}}$ ). Patterns of $\tau_{\mathrm{b}} / \tau_{\mathrm{d}}$ for the six periods are shown in Figure 5. During periods 1 and 3 , when velocities were high, patterns of $\tau_{\mathrm{b}} / \tau_{\mathrm{d}}$ were similar, with a slippery region dominating in the middle and upper tongue and a sticky spot in the lower tongue (Fig. 5a and c). In periods 4 and 6 , when velocities were also high, patterns of $\tau_{\mathrm{b}} / \tau_{\mathrm{d}}$ were similar (but contrasted with those in periods 1 and 3), with a large slippery spot in the lower tongue, a large slippery region in the upper tongue, and a sticky spot between them in the middle tongue (Fig. $5 \mathrm{~d}$ and f). In periods 2 and 5, which shared similarly low velocities and negligible strain rates, there were contrasting $\tau_{\mathrm{b}} / \tau_{\mathrm{d}}$ patterns (Fig. 5b and e). Period 2 had fairly uniform $\tau_{b} / \tau_{d}$ values close to unity across the tongue, indicating driving stresses were resisted almost entirely by basal drag (but with a slight sticky spot in the middle tongue). Conversely, $\tau_{\mathrm{b}} / \tau_{\mathrm{d}}$ was highly variable in period 5 , with a marked slippery spot in the middle tongue surrounded by sticky regions in the lower and upper tongue.

\section{Meteorology and hydrology}

Air-temperature and rainfall data are shown in Figure 6. This 35 day period was the warmest period of the year. Discharge and turbidity in the eastern and western proglacial streams are shown in Figure $7 \mathrm{a}$, while Figure $7 \mathrm{~b}$ shows total daily runoff from the glacier, and the subglacial discharge estimated from the mixing model. Figure $7 \mathrm{a}$ shows that $\sim 76 \%$ of the total discharge drains from the east, while $\sim 24 \%$ drains from the west. The western stream discharge showed little response to changing temperatures other than diurnal variations and showed only small daily turbidity peaks. This stream carries mainly supraglacial and icemarginal discharge (Irvine-Fynn and others, 2005). Discharge in the eastern stream was always greater. There are clear diurnal discharge and turbidity variations in the eastern stream, but more marked fluctuations also occur in response to longer-term, day-to-day temperature fluctuations. One of the most notable features of the eastern stream is the large increase in both discharge and turbidity after day 198 (Fig. 7a). This was associated with a rapid increase in discharge from the subglacially fed upwelling, which reached seasonal maximum values on day 201 (Fig. 7b).

The air-temperature data were used to drive a simple degree-day melt model in order to calculate the daily meltwater inputs to the glacier. Degree-day factors were determined following an analysis of 6 years of meteorological and ablation data by Brinkhaus (2003). This work found that the ablation conditions in 1999 were best and most simply represented by the application of an average degree-day factor for all summers from 1997 to 2001 $\left(8.75 \mathrm{~mm} \mathrm{~d}^{-1}{ }^{\circ} \mathrm{C}^{-1}\right)$ and a lapse rate of $0.0065^{\circ} \mathrm{C} \mathrm{m}^{-1}$. The average degree-day factor compares favourably with degreeday factors found by other workers for glaciers in Switzerland, France, Norway, Arctic Canada, Patagonia, North Greenland and Sweden (see Braithwaite and Zhang, 2000, table 4).

Modelled daily melt was calculated by multiplying the degree-day factor by the mean daily temperature in a number of $50 \mathrm{~m}$ elevation zones. These zones represent those adopted by the Norsk Polarinstitutt mass-balance monitoring programme (e.g. Hagen and Liestøl, 1990). The modelled inputs to the glacier were then compared with measured discharge in the proglacial streams in order to estimate patterns of daily water storage (Fig. 8). In the western stream, modelled inputs match measured outputs reasonably accurately (Fig. 8a). Small discrepancies are probably due to the weaknesses in the model rather than any subtle variations in water storage (Fig. 8c). However, there were significant differences between inputs and outputs in the eastern stream, which we interpret in terms of waterstorage variations (Fig. 8b). Virtually all of the stored water release may be accounted for by subglacial drainage (Fig. 8c; cf. Fig. 7b). Thus the switch to net runoff release is coincident with the rapid increase in subglacial drainage (around day 198).

The air-temperature and proglacial stream discharge data were also used to investigate the lag times between diurnal temperature and discharge fluctuations. Lag times give some indication of the speed at which meltwater is routed through the glacier's drainage system and therefore the hydraulic efficiency of the drainage pathways (Gurnell and others, 1992). In each period, the lag with the highest correlation coefficient is used as a surrogate for the time lag between melting at the surface and the arrival of that water in the proglacial streams (Fig. 9). In the western stream, there was a reduction in lag between periods 1 and 3 from 8 to 3 hours. Thereafter, the lag remained at 3 hours except for the temporary increase to 6 hours in period 5. This implies a gradual increase in the hydraulic efficiency of the glacier drainage system feeding the western stream during the first half of the summer, as air temperatures and discharges generally rose, with a temporary reduction in efficiency during the low air temperatures and discharges of period 5. In the eastern stream, the lag was already only 3 hours in 

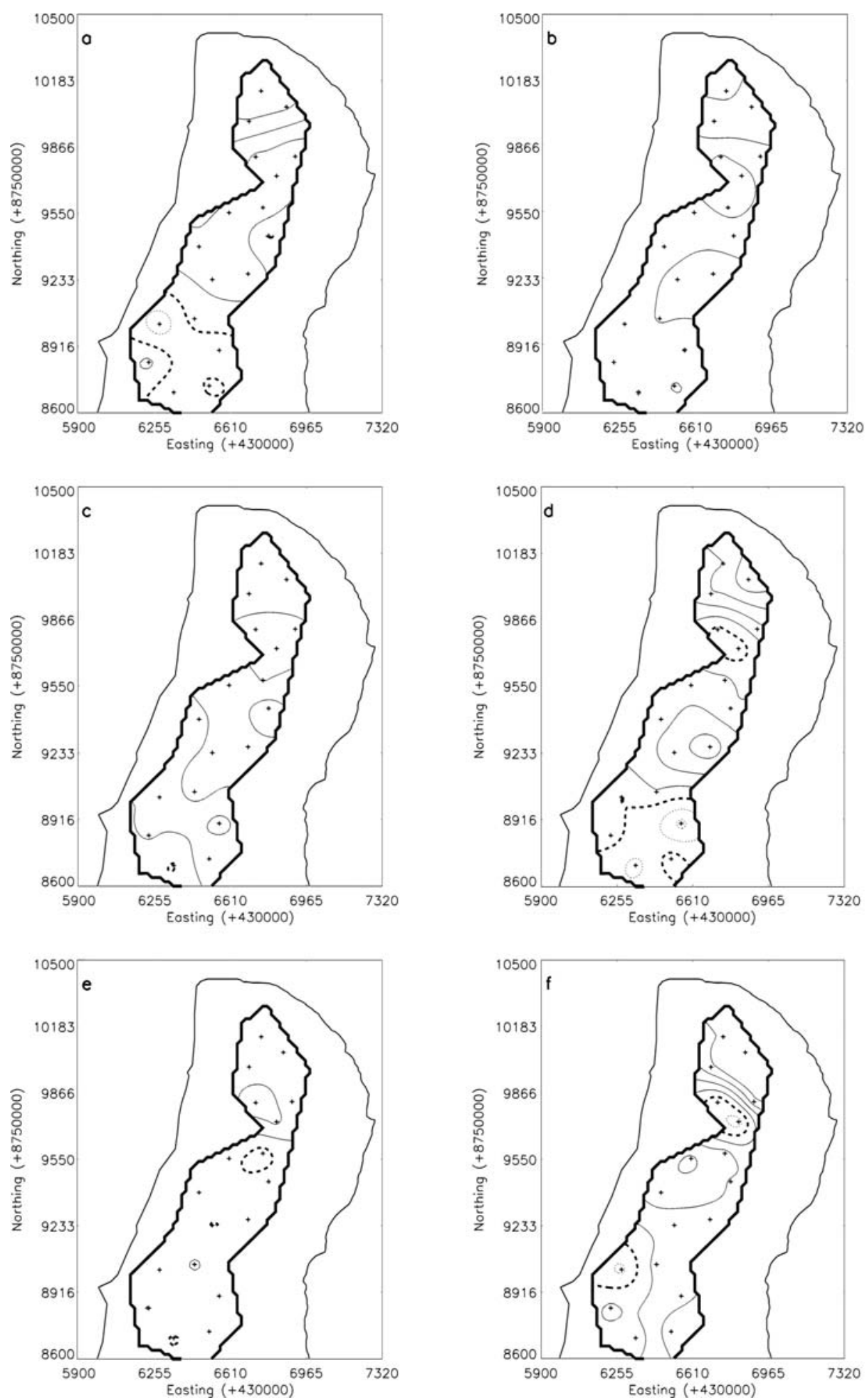

Fig. 4. Longitudinal strain rate in the tongue. Strain rates were calculated for the centre of each strain triangle (marked with crosses), and then interpolated across the region covered by the stake network. Positive longitudinal strains indicate extension and are marked with fine dotted contours. Negative strains indicate compression and are marked with fine solid contours. The thick dashed contour is where strain rates are zero. (a) Period 1 (5-9 July); (b) period 2 (9-15 July); (c) period 3 (15-20 July); (d) period 4 (20-23 July); (e) period 5 (23 July-6 August); and (f) period 6 (6-9 August).

period 1. This increased to 7 hours during the low air temperatures and discharges of period 2, before returning again in period 3 to 3 hours. Thereafter, there was a lack of any clear lag in periods 4 and 5 . Thus, the drainage system feeding the eastern stream did not evolve through the early summer and did not route the meltwater in a systematic way during the late summer as it had done on the western side.

\section{DISCUSSION}

Despite the apparent similarities in the surface velocity patterns during periods $1,3,4$ and 6 when the glacier was moving relatively fast, force-balance analysis suggests that the forcing mechanisms were different. Similarly, the forcing mechanisms during periods 2 and 5 , when the glacier slowed 

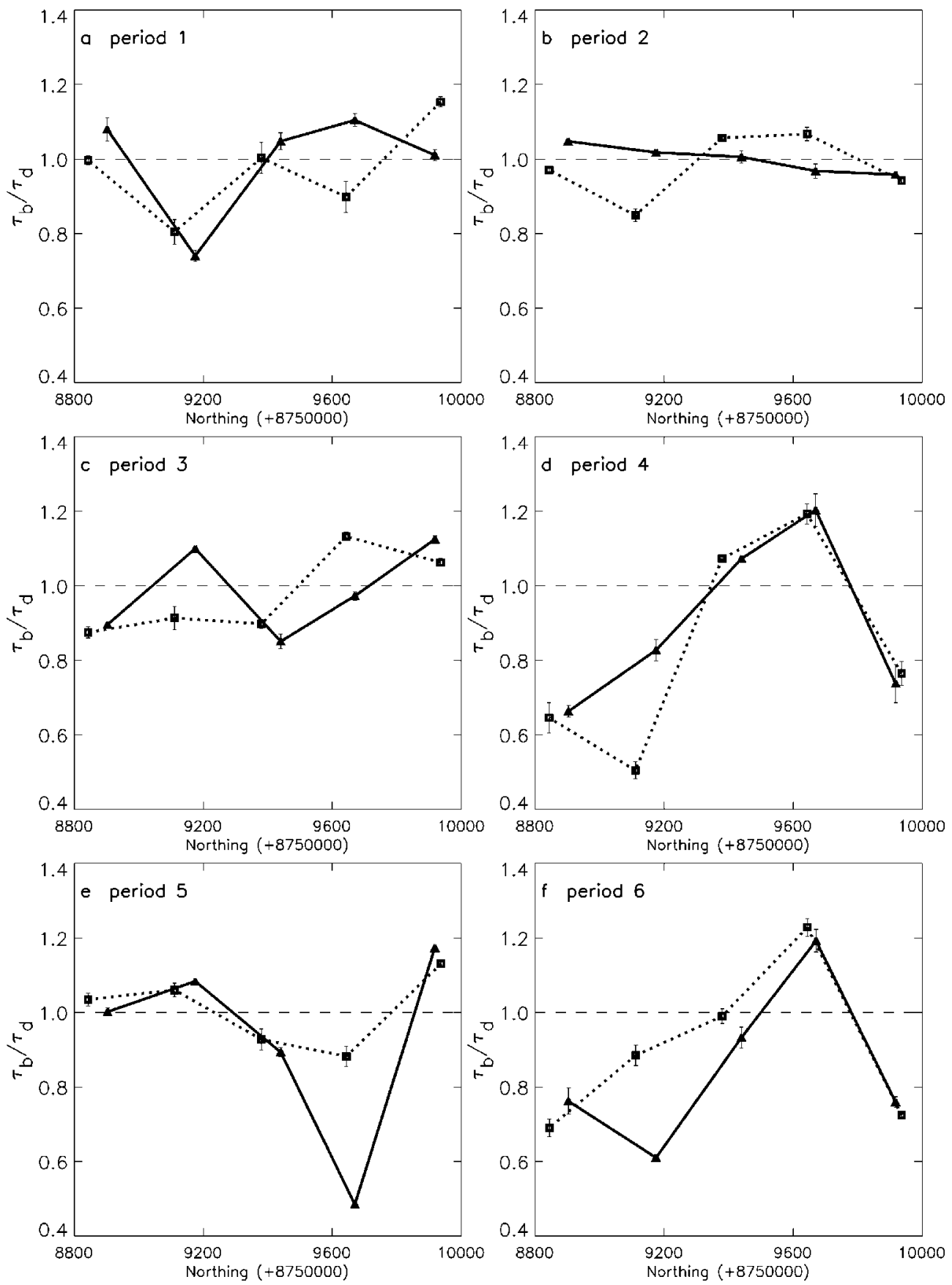

Fig. 5. Ratio of basal drag to driving stress $\left(\tau_{b} / \tau_{d}\right)$ in the tongue. The glacier terminus is to the right (increasing northing). Solid lines and triangles represent the western line of force-balance blocks, while dotted lines and squares represent the eastern line of blocks. Where $\tau_{\mathrm{b}} / \tau_{\mathrm{d}}<1$, some resistance to flow comes from non-local sources (a slippery spot). Where $\tau_{\mathrm{b}} / \tau_{\mathrm{d}}>1$, flow is driven by forces in addition to the driving force (a sticky spot). Error bars representing the standard deviation are shown. (a) Period 1 (5-9 July); (b) period 2 (9-15 July); (c) period 3 (15-20 July); (d) period 4 (20-23 July); (e) period 5 (23 July-6 August); and (f) period 6 (6-9 August).

down, also appear to be different. The relative importance of local vs non-local forcing may be explained with reference to meteorological and hydrological parameters.

High velocities in periods 1 and 3 (Fig. 3a and c) correspond to the development of a slippery spot in the middle tongue (Fig. $5 \mathrm{a}$ and c). We envisage that a distributed subglacial drainage system expands over large parts of the bed beneath the middle tongue during these periods. We interpret this as being associated with subglacial ponding of stored water above the thermomechanical dam at the boundary between temperate and cold basal ice (Fig. 1). This interpretation is supported by our water-balance calculations showing net storage of water during periods $1-3$ (Fig. 8), and our air-temperature/discharge lag-time calculations showing relatively hydraulically inefficient drainage, particularly towards the east, during periods 1-3 (Fig. 9). Thus, we suggest high velocities in the middle tongue may have been locally forced due to water storage and high water pressures, while high velocities further up- and down-glacier occurred by longitudinal coupling to the middle-tongue slippery spot. This explanation holds for period 3, despite the emergence of pressurized subglacial water from storage halfway through this period (Fig. 8c), suggesting the initial release of water was insufficient to raise subglacial water pressures 


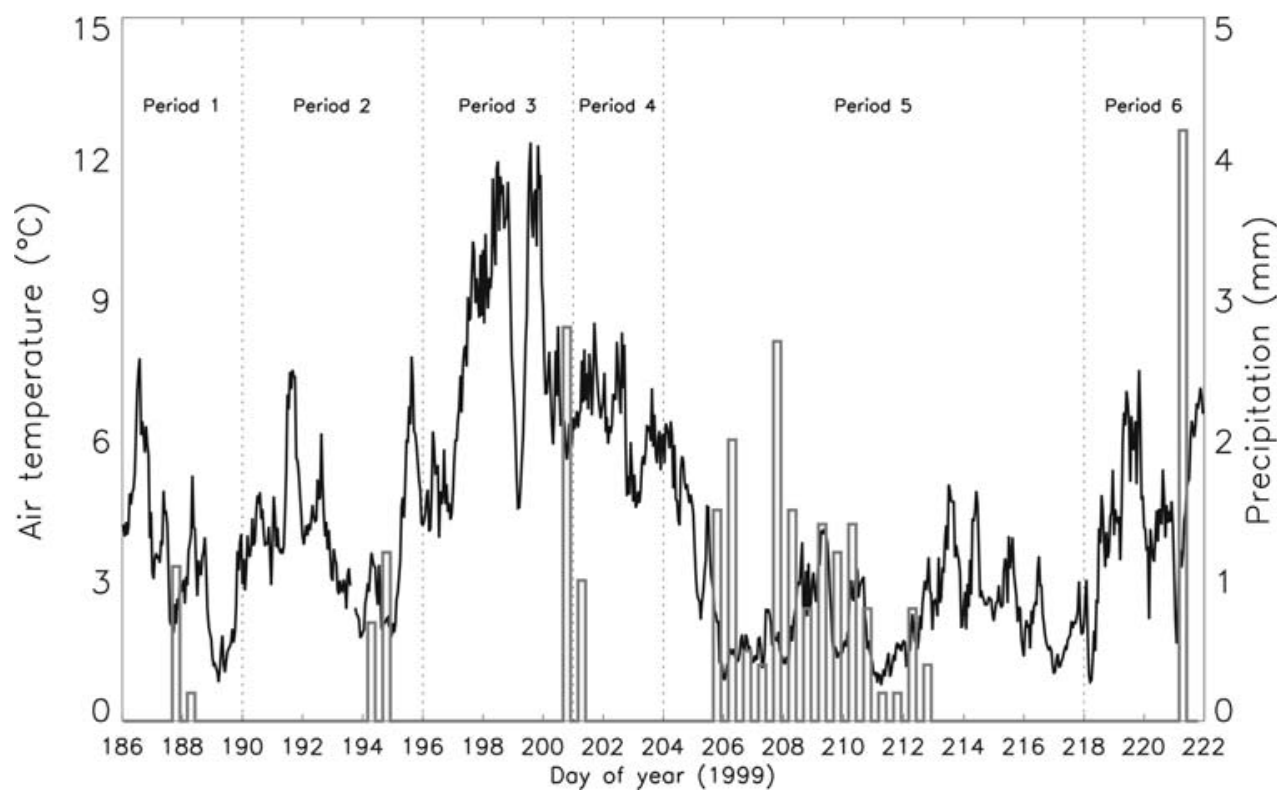

Fig. 6. Mean hourly air temperature $\left({ }^{\circ} \mathrm{C}\right)$ (thick black line) and 12 hourly precipitation totals $(\mathrm{mm})$ (thin bars) during summer 1999 . Air temperatures never fell below $0^{\circ} \mathrm{C}$, so all precipitation was rain. The six intra-summer periods are marked.

and reduce basal drag beneath large parts of the lower tongue (Fig. 5c). This suggests that the subglacial drainage pathway that developed beneath the cold-based lower tongue was spatially restricted.

High velocities also occurred in periods 4 and 6 (Fig. 3d and $\mathrm{f}$ ), despite the loss of the slippery spot beneath the middle tongue (Fig. $5 \mathrm{~d}$ and $\mathrm{f}$ ). In both cases, rapid, large surface water inputs (rain in period 4 and rain and melt in period 6; Fig. 6) to the subglacial drainage system appear to have triggered the release of large volumes of stored water from the middle tongue at the thermomechanical dam (Fig. 8b). This would have reduced subglacial water pressures in the middle tongue and would explain the high basal drag values there in periods 4 and 6 (Fig. $5 \mathrm{~d}$ and f). Rapid routing of water to the spatially restricted subglacial drainage system beneath the lower tongue would have raised water pressures there, promoted hydraulic jacking and perhaps allowed water to drain from the middle tongue through the lower tongue via an expanding subglacial drainage network. This would have increased the hydraulic efficiency of the glacier's drainage system, which is supported by the reduction in airtemperature/discharge lag times after period 3 (Fig. 9). This may also account for the low basal drag values beneath the lower tongue during periods 4 and 6 (Fig. $5 \mathrm{~d}$ and f).

Low velocities in periods 2 and 5 (Fig. $3 \mathrm{~b}$ and e) appear to have occurred for slightly different reasons. In period 2 the middle-tongue slippery spot was likely removed (Fig. 5b) as a consequence of moderate air temperatures (Fig. 6) and slow, sustained water inputs to the subglacial drainage system enabling the steady, gradual enlargement of certain drainage pathways, and the drainage of water from other parts of the glacier bed. This is supported by our waterbalance calculations suggesting drainage of water from storage during the latter part of period 2 (Fig. 8b), although some of this is likely to be water from supraglacial and icemarginal locations, as the subglacial contribution to runoff was small at this time (Fig. 7b). In period 5, low air temperatures (Fig. 6) meant low water inputs and a sustained drainage of subglacial water from the glacier (Figs $7 \mathrm{~b}$ and 8c). There were large increases in basal drag beneath the lower and upper tongue (Fig. 5e), presumably associated with the removal of water and closure of drainage elements over large parts of the bed in these locations. Conversely, a slippery spot developed beneath the middle tongue again (Fig. 5e), likely as a result of the re-establishment of the thermomechanical dam and the drainage of water from the upper tongue to the middle tongue.

Intra-summer variations in surface velocity patterns across the tongue of midre Lovénbreen may thus be explained by changes in patterns of basal drag as a result of changes in the morphology of the subglacial drainage system (size, shape and degree of interconnection), brought about by varying water inputs, but also controlled by basal thermal regime. When water inputs are moderate or low (e.g. periods 2 and 5), gradual enlargement of some drainage elements leads to a drop in subglacial water pressures over large parts of the glacier bed. When water inputs are high and persistent, pressures increase, but enlargement of drainage elements and an increase in hydraulic connection over parts of the bed prevents pressures at the thermomechanical dam from becoming too high, allowing ponding to occur. If, however, there is a very rapid pressure increase due to sudden inputs of water from melting or rainfall, we propose that pressures may increase sufficiently to breach the dam, allowing stored water to drain at high pressures beneath large parts of the cold-based lower tongue.

Until recently, the mechanisms responsible for intraseasonal velocity variations of polythermal glaciers have remained largely unresolved (e.g. Iken, 1974; Rabus and Echelmeyer, 1997). However, our work indicates that the main controls are in essence the same as those on temperate glaciers, i.e. the distribution and pressure of subglacial water (e.g. Iken and others, 1983; Meier and others, 1994; Willis, 1995). As in temperate glaciers, when the subglacial drainage system is poorly developed and of low capacity, rapid inputs of water that exceed its capacity result in hydraulic instabilities which may lead to enhanced motion (Iverson and others, 1995). Similar conclusions were 

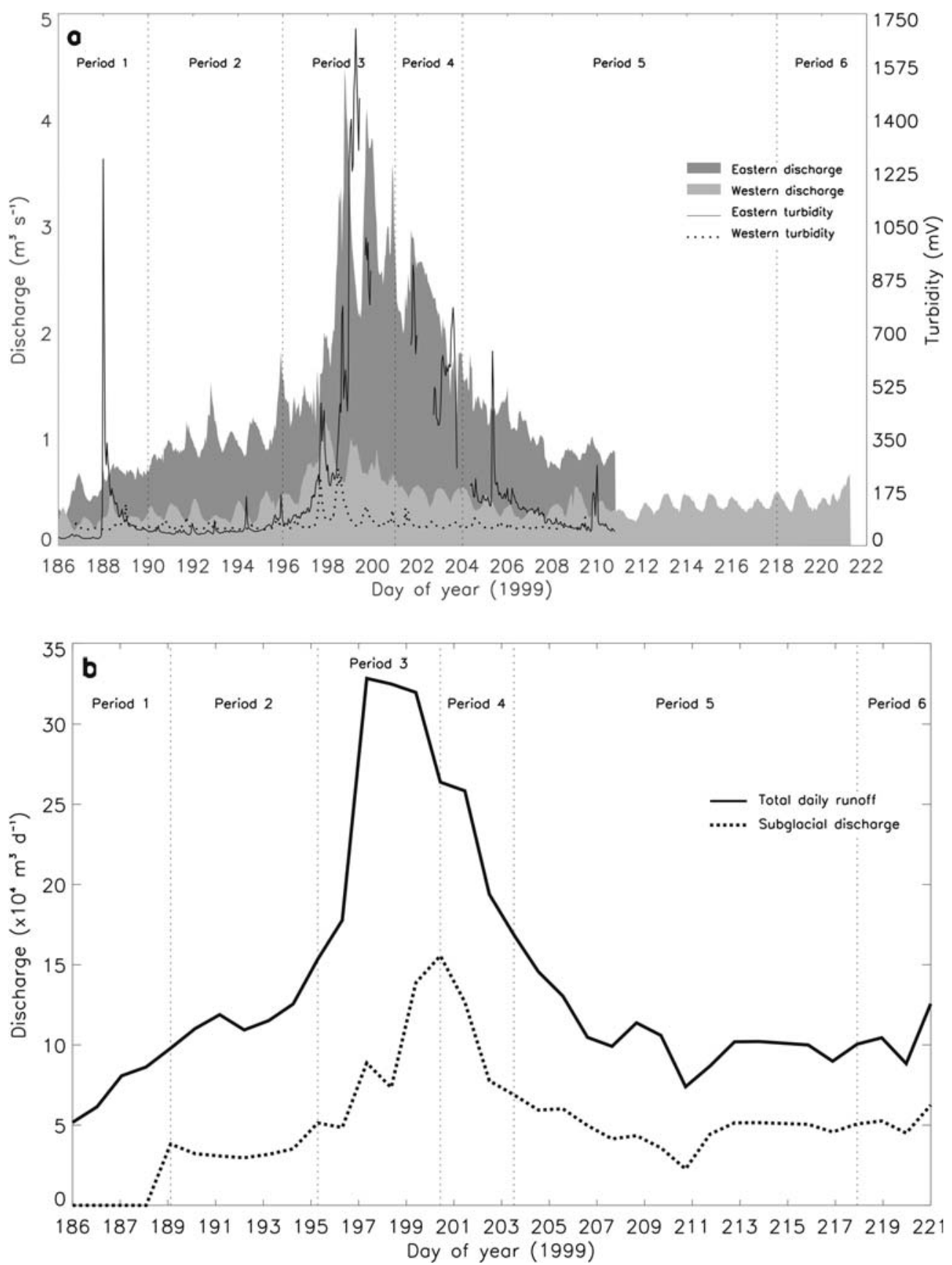

Fig. 7. (a) Proglacial discharge (in $\mathrm{m}^{3} \mathrm{~s}^{-1}$ ) and turbidity (in $\mathrm{mV}$, logged directly from the turbidity sensor) time series in 1999 for the eastern and western outlets. The six intra-summer periods are marked. (b) Total (measured) daily runoff and (modelled) subglacial discharge (both in $\left.\mathrm{m}^{3} \mathrm{~d}^{-1}\right)$.

reached from the measurement of surface velocity variations across the polythermal Trapridge Glacier, Yukon Territory, Canada, and John Evans Glacier (Kavanaugh and Clarke, 2001; Copland and others, 2003).

Although there are similarities with temperate glaciers, the role of large regions of cold basal ice is unique to polythermal glaciers. Our study has also shown that the presence of a large region of cold basal ice in the lower tongue acts as an important sticky spot, and has a damming effect which results in high subglacial water pressures upglacier of the dam, and thus high velocities here. Similar, tentative conclusions were reached on the polythermal Kitdlerssuaq Glacier, West Greenland, where summer velocity increases in the upper ablation area were attributed to high basal water pressures caused by the backing-up of meltwater at the bed, due to inefficient drainage in the ablation area (Andreasen, 1985). Work on John Evans Glacier also highlights the importance of the thermal dam on the flow of basal water in controlling surface velocity patterns on polythermal glaciers (Copland and others, 2003).

\section{CONCLUSIONS}

We believe this to be the first study that has attempted to analyze the changing balance of forces associated with intra-seasonal velocity variations on a polythermal glacier. Taking into account the limitations of the force-balance method employed, our work has suggested that for much of the time, short-term velocity variations in the lower tongue of midre Lovénbreen are entirely non-locally forced by 

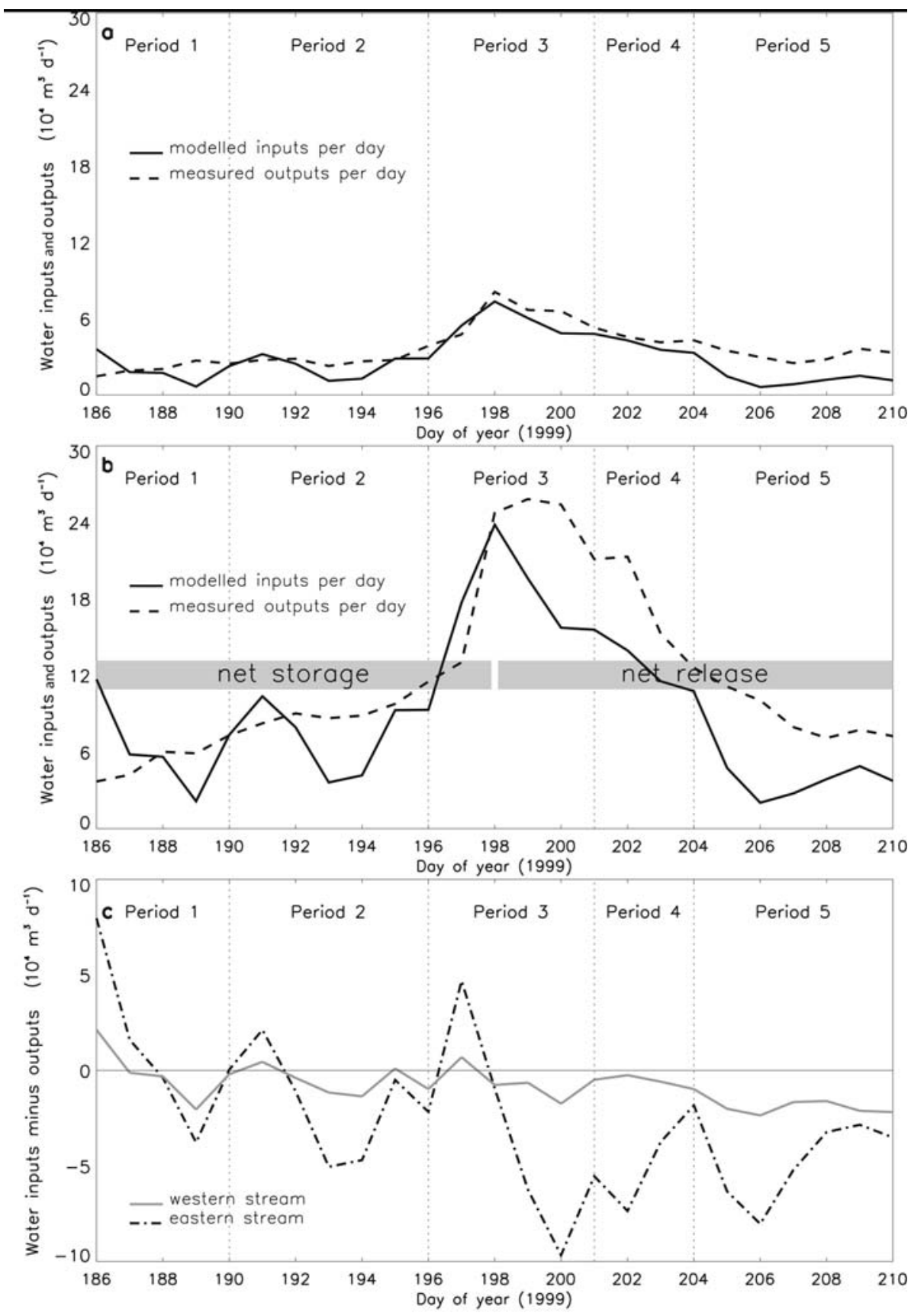

Fig. 8. (a, b) Modelled and measured daily water inputs to and outputs from the western stream (a) and eastern stream (b). (c) The difference between inputs and outputs in the eastern and western streams. A positive difference indicates less water exiting the glacier than would be expected given the recorded temperatures, and thus water going into storage; while a negative difference indicates more water exiting the glacier than would be expected, and thus water being released from storage. Water balance is shown up to day 210 only, since there was no eastern discharge record after this.

up-glacier coupling. However, basal drag is reduced for short periods in the lower tongue, when water that has been stored above the thermal dam forces its way at high pressures through the cold-based margin. When this occurs, increases in velocity here are locally forced, but are also often limited by coupling to areas of high basal drag upglacier and to the sides.

These findings have major implications since they indicate that subglacial drainage can occur under and through cold basal ice. Further study is recommended however, because of the likely changes in the relative distribution of cold and temperate ice in polythermal glaciers under a warming climate, and the implications of this for hydrology and dynamics. This work also has implications for our understanding of cold-based glaciers, which may be more dynamic than previously thought.

\section{ACKNOWLEDGEMENTS}

This work was carried out while D.M.R. was in receipt of UK Natural Environment Research Council (NERC) studentship GT04/97/57/FS. Additional financial assistance for fieldwork came from St John's College, Cambridge; The Dudley Stamp Memorial Fund (The Royal Society); and the Philip Lake 

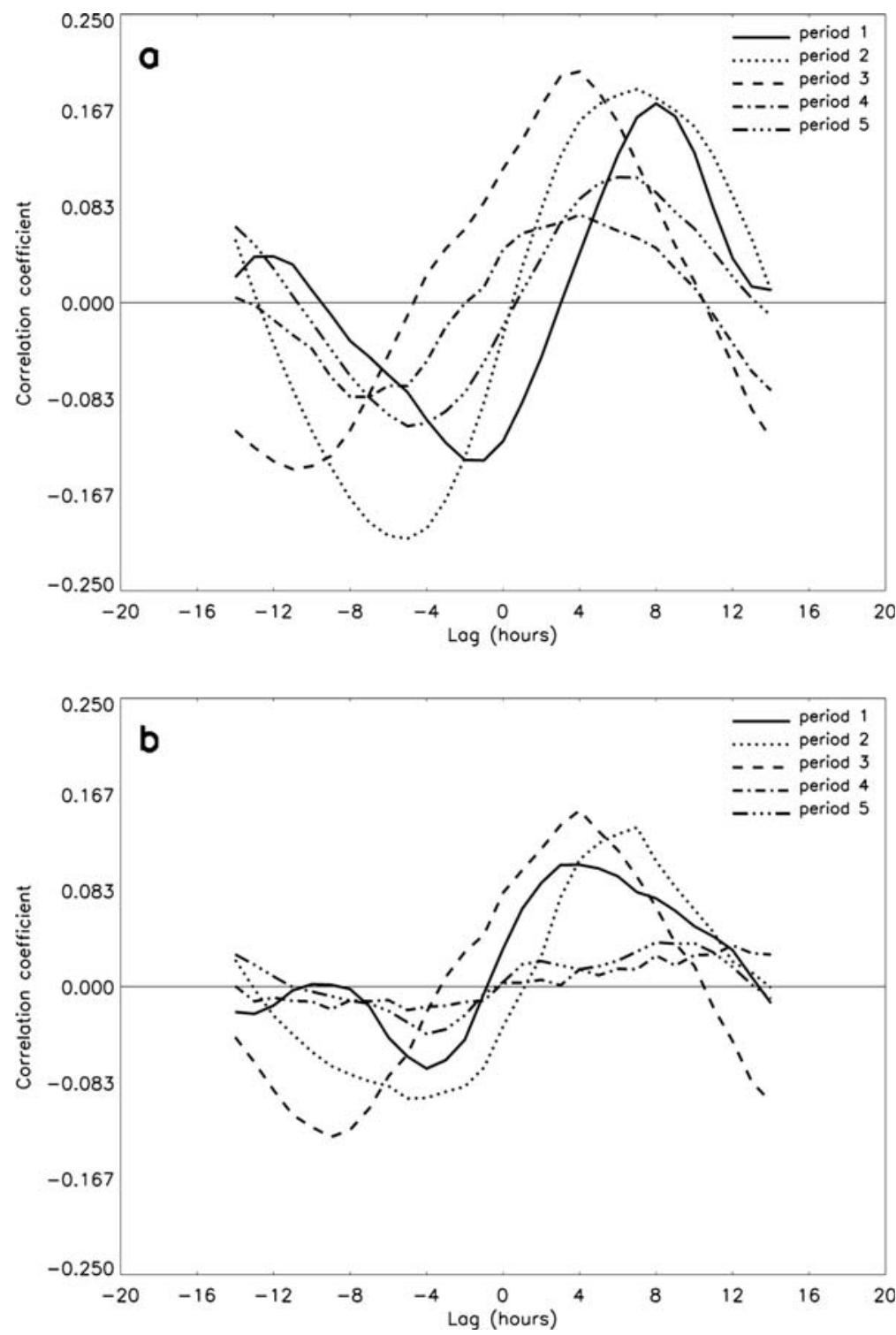

Fig. 9. The correlation coefficients between air temperature and discharge associated with different lag times in the western outlet (a) and eastern outlet (b), in periods 1-5, when a full discharge record was available. Data were differenced to remove trends, and smoothed over a 5 hour period, using a centred 5 hour moving average. For each period, the greatest correlation coefficient indicates the average time lag between melting at the surface and discharge in the proglacial streams.

Fund, B.B. Roberts Fund, Tennant Fund and Worts Travelling Scholars Fund (all University of Cambridge). A.J.H. acknowledges the Nuffield Newly Appointed Lecturers Scheme. We thank N. Cox at the NERC Arctic Research Station for logistical support, and N. Rippin, M. Holdaway, R. Jenkins, E. Blyth and A. Morris for help in the field. Additionally, we thank D. Mair for making his force-balance programs available and for assistance in their modification and application, and J. Moore for useful discussion. Finally, we are grateful to $\mathrm{H}$. Blatter, an anonymous referee and the scientific editor, R. Naruse, who helped to improve this paper considerably.

\section{REFERENCES}

Andreasen, J.O. 1985. Seasonal surface-velocity variations on a subpolar glacier in West Greenland. J. Glaciol., 31(109), 319-323.

Arctic Climate Impact Assessment (ACIA). 2004. Impacts of a warming Arctic: Arctic climate impact assessment. Cambridge, Cambridge University Press.
Arnold, N.S. and M.J. Sharp. 1992. Influence of glacier hydrology on the dynamics of a large Quaternary ice sheet. J. Quat. Sci., $7(2), 109-124$.

Björnsson, H. and 6 others. 1996. The thermal regime of sub-polar glaciers mapped by multi-frequency radio-echo sounding. J. Glaciol., 42(140), 23-32.

Blake, E.W., U.H. Fischer and G.K.C. Clarke. 1994. Direct measurement of sliding at the glacier bed. J. Glaciol., 40(136), 595-599.

Blatter, H. 1995. Velocity and stress fields in grounded glaciers: a simple algorithm for including deviatoric stress gradients. J. Glaciol., 41(138), 333-344.

Braithwaite, R.J. and Y. Zhang. 2000. Sensitivity of mass balance of five Swiss glaciers to temperature changes assessed by tuning a degree-day model. J. Glaciol., 46(152), 7-14.

Brinkhaus, M. 2003. Modelling melt and runoff on a High Arctic glacier: Midre Lovénbreen, Svalbard. (MSc thesis, University of Bochum.)

Copland, L., M.J. Sharp and P.W. Nienow. 2003. Links between short-term velocity variations and the subglacial hydrology of a predominantly cold polythermal glacier. J. Glaciol., 49(166), $337-348$. 
Echelmeyer, K. and Z. Wang. 1987. Direct observation of basal sliding and deformation of basal drift at sub-freezing temperatures. J. Glaciol., 33(113), 83-98.

Fischer, U.H. and G.K.C. Clarke. 1997. Stick-slip sliding behaviour at the base of a glacier. Ann. Glaciol., 24, 390-396.

Fischer, U.H. and G.K.C. Clarke. 2001. Review of subglacial hydromechanical coupling: Trapridge Glacier, Yukon Territory, Canada. Quat. Int., 86, 29-43.

Fleming, K.M., J.A. Dowdeswell and J. Oerlemans. 1997. Modelling the mass balance of northwest Spitsbergen glaciers and responses to climate change. Ann. Glaciol., 24, 203-210.

Gurnell, A.M., M.J. Clark and C.T. Hill. 1992. Analysis and interpretation of patterns within and between hydroclimatological time series in an Alpine glacier basin. Earth Surf. Proc. Land., 17(8), 821-839.

Hagen, J.O. and O. Liestöl. 1990. Long-term glacier mass-balance investigations in Svalbard, 1950-88. Ann. Glaciol., 14, 102-106.

Hambrey, M.J., M.R. Bennett, J.A. Dowdeswell, N.F. Glasser and D. Huddart. 1999. Debris entrainment and transfer in polythermal valley glaciers. J. Glaciol., 45(149), 69-86.

Hansen, S. 2003. From surge-type to non-surge-type glacier behaviour: midre Lovénbreen, Svalbard. Ann. Glaciol., 36, 97-102.

Heine, J.T. and D.F. McTigue. 1996. A case for cold-based continental ice sheets - a transient thermal model. J. Glaciol., 42(140), 37-42.

Hodson, A.J. and R.I. Ferguson. 1999. Fluvial suspended sediment transport from cold and warm-based glaciers in Svalbard. Earth Surf. Proc. Land., 24(13), 957-974.

Hodson, A.J., M. Tranter and G. Vatne. 2000. Contemporary rates of chemical denudation and atmospheric $\mathrm{CO}_{2}$ sequestration in glacier basins: an Arctic perspective. Earth Surf. Proc. Land., 25, 1447-1471.

Hooke, R.LeB. 1981. Flow law for polycrystalline ice in glaciers: comparison of theoretical predictions, laboratory data, and field measurements. Rev. Geophys. Space Phys., 19(4), 664-672.

Hooke, R.LeB., P. Calla, P. Holmlund, M. Nilsson and A. Stroeven. 1989. A 3 year record of seasonal variations in surface velocity, Storglaciären, Sweden. J. Glaciol., 35(120), 235-247.

Iken, A. 1974. Velocity fluctuations of an Arctic valley glacier; a study of the White Glacier, Axel Heiberg Island, Canadian Arctic Archipelago. Axel Heiberg Isl. Res. Rep. McGill Univ., Glaciol., 5.

Iken, A. and R.A. Bindschadler. 1986. Combined measurements of subglacial water pressure and surface velocity of Findelengletscher, Switzerland: conclusions about drainage system and sliding mechanism. J. Glaciol., 32(110), 101-119.

Iken, A. and M. Truffer. 1997. The relationship between subglacial water pressure and velocity of Findelengletscher, Switzerland, during its advance and retreat. J. Glaciol., 43(144), 328-338.

Iken, A., H. Röthlisberger, A. Flotron and W. Haeberli. 1983. The uplift of Unteraargletscher at the beginning of the melt season a consequence of water storage at the bed? J. Glaciol., 29 (101), 28-47.

Irvine-Fynn, T.D.L. and 7 others. 2005. Geocryological processes linked to High Arctic proglacial stream suspended sediment dynamics: examples from Bylot Island, Nunavut, and Spitsbergen, Svalbard. Hydrol. Process., 19(1), 115-135.

Iverson, N.R., B. Hanson, R.LeB. Hooke and P. Jansson. 1995. Flow mechanism of glaciers on soft beds. Science, 267(5194), 80-81.

Jiskoot, H., T. Murray and P. Boyle. 2000. Controls on the distribution of surge-type glaciers in Svalbard. J. Glaciol., 46(154), 412-422.
Kamb, B. and H. Engelhardt. 1987. Waves of accelerated motion in a glacier approaching surge: the mini-surges of Variegated Glacier, Alaska, U.S.A. J. Glaciol., 33(113), 27-46.

Kavanaugh, J.L. and G.K.C. Clarke. 2001. Abrupt glacier motion and reorganization of basal shear stress following the establishment of a connected drainage system. J. Glaciol., 47(158), 472-480.

Lefauconnier, B., J.O. Hagen, J.B. Örbæk, K. Melvold and E. Isaksson. 1999. Glacier balance trends in the Kongsfjorden area, western Spitsbergen, Svalbard, in relation to the climate. Polar Research, 18(2), 307-313.

Liestøl, O. 1988. The glaciers in the Kongsfjorden area, Spitsbergen. Norsk Geografisk Tidsskrift, 42(4), 231-238.

Lliboutry, L. 1987. Realistic, yet simple bottom boundary conditions for glaciers and ice sheets. J. Geophys. Res., 92(B9), 9101-9109.

Mair, D.W.F. 1997. Hydrological influences on the dynamics of valley glaciers. (PhD dissertation, University of Cambridge.)

Mair, D., P. Nienow, I. Willis and M. Sharp. 2001. Spatial patterns of glacier motion during a high-velocity event: Haut Glacier d'Arolla, Switzerland. J. Glaciol., 47(156), 9-20.

McCarthy, J.J., O.F. Canziani, N.A. Leary, D.J. Dokken and K.S. White. 2001. Climate change 2001: impacts, adaptation, and vulnerability. Cambridge, etc., Cambridge University Press.

Meier, M. and 9 others. 1994. Mechanical and hydrologic basis for the rapid motion of a large tidewater glacier. 1. Observations. J. Geophys. Res., 99(B8), 15,219-15,229.

Mumford, P.N. 2002. Nutrient budgets and transport dynamics in a High Arctic glacier basin, Svalbard. (PhD thesis, University of Sheffield.)

Payne, A.J. and 10 others. 2000. Results from the EISMINT model intercomparison: the effects of thermomechanical coupling. J. Glaciol., 46(153), 227-238.

Rabus, B.T. and K.A. Echelmeyer. 1997. The flow of a polythermal glacier: McCall Glacier, Alaska, U.S.A. J. Glaciol., 43(145), 522-536.

Ramsay, J.G. 1967. The folding and fracturing of rocks. New York, McGraw-Hill.

Rippin, D.M. 2002. The hydrology and dynamics of polythermal glaciers: Midre Lovénbreen, Svalbard. (PhD dissertation, University of Cambridge.)

Rippin, D. and 6 others. 2003. Changes in geomety and subglacial drainage of Midre Lovénbreen, Svalbard, determined from digital elevation models. Earth Surf. Proc. Land., 28(3), 273-298.

Röthlisberger, H. and A. Iken. 1981. Plucking as an effect of waterpressure variations at the glacier bed. Ann. Glaciol., 2, 57-62.

Sharp, M., G.H. Brown, M. Tranter, I.C. Willis and B. Hubbard. 1995. Comments on the use of chemically based mixing models in glacier hydrology. J. Glaciol., 41(138), 241-246.

Van der Veen, C.J. 1999. Fundamentals of glacier dynamics. Rotterdam, etc., A.A. Balkema Publishers.

Van der Veen, C.J. and I.M. Whillans. 1989a. Force budget: I. Theory and numerical methods. J. Glaciol., 35(119), 53-60.

Van der Veen, C.J. and I.M. Whillans. 1989b. Force budget: II. Application to two-dimensional flow along Byrd Station Strain Network, Antarctica. J. Glaciol., 35(119), 61-67.

Waller, R.I. 2001. The influence of basal processes on the dynamic behaviour of cold-based glaciers. Quat. Int., 86, 117-128.

Willis, I.C. 1995. Intra-annual variations in glacier motion: a review. Progress in Physical Geography, 19(1), 61-106. 